\title{
Methods for Estimating Water Withdrawals for Mining in the United States, 2005
}

Scientific Investigations Report 2009-5053 
Cover: Hydraulic mining near Virginia City, Madison County, Mont., 1871. Alder Gulch is 16 miles in length, rising in the mountains near Madison River at an altitude of 7,500 feet. A flume is laid upon the bedrock, in the bottom of the gulch, and the waters of the creek brought through it, carrying with its current the auriferous sands. Photograph by W.H. Jackson, U.S. Geological Survey. 


\section{Methods for Estimating Water Withdrawals for Mining in the United States, 2005}

By John K. Lovelace

Scientific Investigations Report 2009-5053 


\section{U.S. Department of the Interior \\ KEN SALAZAR, Secretary}

\section{U.S. Geological Survey Suzette M. Kimball, Acting Director}

U.S. Geological Survey, Reston, Virginia: 2009 This and other USGS information products are available at http://store.usgs.gov/
U.S. Geological Survey
Box 25286 , Denver Federal Center
Denver, CO 80225
To learn about the USGS and its information products visit http://www.usgs.gov/
1-888-ASK-USGS

Any use of trade, product, or firm names is for descriptive purposes only and does not imply endorsement by the U.S. Government.

Although this report is in the public domain, permission must be secured from the individual copyright owners to reproduce any copyrighted materials contained within this report.

Suggested citation:

Lovelace, J.K., 2009, Methods for estimating water withdrawals for mining in the United States, 2005: U.S.

Geological Survey Scientific Investigations Report 2009-5053, 7 p. 


\section{Contents}

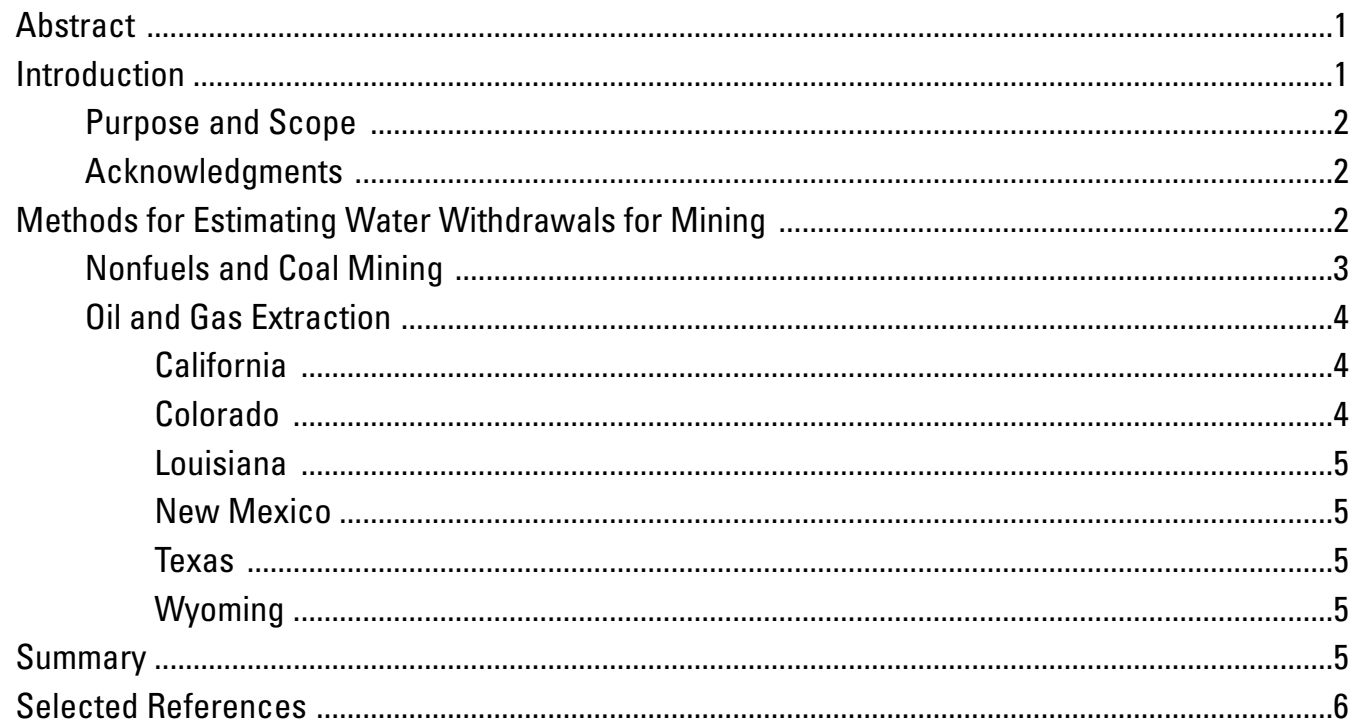

\section{Tables}

1. Water-use coefficients for mining in the United States by major Standard Industrial Classification group

\section{Conversion Factors}

\begin{tabular}{lll}
\hline \multicolumn{1}{c}{ Multiply } & \multicolumn{1}{c}{ By } & \multicolumn{1}{c}{ To obtain } \\
$\begin{array}{l}\text { barrel (bbl), (petroleum, } \\
1 \text { barrel=42 gal) }\end{array}$ & 0.1590 & cubic meter $\left(\mathrm{m}^{3}\right)$ \\
gallon & 3.785 & liter $(\mathrm{L})$ \\
gallon per minute (gal/min) & 0.06309 & liter per second $(\mathrm{L} / \mathrm{s})$ \\
gallon per day (gal/d) & 3.785 & liter per day \\
million gallons per day (Mgal/d) & 1.121 & thousand acre-feet per year \\
& 0.001547 & thousand cubic feet per second \\
& 0.6944 & thousand gallons per minute \\
& 0.003785 & million cubic meters per day \\
& 1.3815 & million cubic meters per year \\
metric ton (1 megagram) & 1.1023 & short ton $(2,000$ pounds $)$ \\
\hline
\end{tabular}

Abbreviated water-quality units used in this report: Chemical concentrations are given in metric units. Chemical concentration is given in milligrams per liter ( $\mathrm{mg} / \mathrm{L})$. Milligrams per liter are units expressing the concentration of chemical constituents in solution as weight (milligrams) of solute per unit volume (liter) of water. For concentrations less than $7,000 \mathrm{mg} / \mathrm{L}$, the numerical value of milligrams per liter is the same as for concentrations in parts per million. 
Blank Page 


\title{
Methods for Estimating Water Withdrawals for Mining in the United States, 2005
}

\author{
By John K. Lovelace
}

\section{Abstract}

The mining water-use category includes groundwater and surface water that is withdrawn and used for nonfuels and fuels mining. Nonfuels mining includes the extraction of ores, stone, sand, and gravel. Fuels mining includes the extraction of coal, petroleum, and natural gas. Water is used for mineral extraction, quarrying, milling, and other operations directly associated with mining activities. For petroleum and natural gas extraction, water often is injected for secondary oil or gas recovery. Estimates of water withdrawals for mining are needed for water planning and management.

This report documents methods used to estimate withdrawals of fresh and saline groundwater and surface water for mining during 2005 for each county and county equivalent in the United States, Puerto Rico, and the U.S. Virgin Islands. Fresh and saline groundwater and surface-water withdrawals during 2005 for nonfuels- and coal-mining operations in each county or county equivalent in the United States, Puerto Rico, and the U.S. Virgin Islands were estimated. Fresh and saline groundwater withdrawals for oil and gas operations in counties of six states also were estimated. Water withdrawals for nonfuels and coal mining were estimated by using mine-production data and water-use coefficients. Production data for nonfuels mining included the mine location and weight (in metric tons) of crude ore, rock, or mineral produced at each mine in the United States, Puerto Rico, and the U.S. Virgin Islands during 2004. Production data for coal mining included the weight, in metric tons, of coal produced in each county or county equivalent during 2004. Water-use coefficients for mined commodities were compiled from various sources including published reports and written communications from U.S. Geological Survey National Water-use Information Program (NWUIP) personnel in several states. Water withdrawals for oil and gas extraction were estimated for six States including California, Colorado, Louisiana, New Mexico, Texas, and Wyoming, by using data from State agencies that regulate oil and gas extraction. Total water withdrawals for mining in a county were estimated by summing estimated water withdrawals for nonfuels mining, coal mining, and oil and gas extraction.
The results of this study were distributed to NWUIP personnel in each State during 2007. NWUIP personnel were required to submit estimated withdrawals for numerous categories of use in their States to a national compilation team for inclusion in a national report describing water use in the United States during 2005. NWUIP personnel had the option of submitting the estimates determined by using the methods described in this report, a modified version of these estimates, or their own set of estimates or reported data. Estimated withdrawals resulting from the methods described in this report may not be included in the national report; therefore the estimates are not presented herein in order to avoid potential inconsistencies with the national report. Water-use coefficients for specific minerals also are not presented to avoid potential disclosure of confidential production data provided by mining operations to the U.S. Geological Survey.

\section{Introduction}

The mining water-use category includes groundwater and surface water that is withdrawn and used for nonfuels and fuels mining. Nonfuels mining includes the extraction of ores, stone, sand, and gravel. Fuels mining includes the extraction of coal, petroleum, and natural gas. Water is used for mining in the extraction of minerals that may be in the form of such solids as iron, sand, gravel, and coal; such liquids as crude petroleum; and gases such as natural gas. Water also is used for quarrying, milling (crushing, screening, washing, and flotation of mined materials), and other activities directly associated with mining. For petroleum and natural gas mining, extracted water often is reinjected for secondary oil or gas recovery. Dewatering is not considered a mining withdrawal unless the water is used beneficially, such as for dampening roads for dust control (Hutson and others, 2004).

Estimates of water withdrawn for mining have been included in U.S. Geological Survey (USGS) reports describing water withdrawals for numerous categories of use in the United States since 1950. From 1950 to 1980, mining withdrawals were included in the self-supplied industrial use category (Solley and others, 1983, p. 4). In 1985, mining was established as a separate category and included water used for washing, milling, dewatering, and other uses that are part of mining activities (Solley and others, 1988, p. 34). Since 
1995, estimates of water removed from mines and quarries for dewatering have not been reported as mining withdrawals unless the water was used for a beneficial purpose, such as dampening roads for dust control (Solley and others, 1998; Hutson and others, 2004). Mining withdrawals typically are less than one percent of total national water use (Solley and others, 1998, p. 44; Hutson and others, 2004, p. 32) and are relatively minor in most States when compared to withdrawals for other categories of use, such as public supply, irrigation, self-supplied industry, and thermoelectric power generation. Estimated withdrawals for mining also are often published in reports of water-use estimates for individual States.

Records of water withdrawn and used at mining operations often are not available. In some States, mining operations are required to maintain water-use records and report usage to a regulatory agency; however, reported use can include reused water as well as dewatering. Most mining operations reuse water to the extent possible, depending on water-quality requirements, water availability, and discharge considerations. State and Federal regulatory agencies often require the reporting of water discharges at mining operations. Discharges often include large volumes dewatered from the mine (Mavis, 2002).

Where water withdrawals for mining are unknown, they often have been estimated by using mineral production data and water-use coefficients (Solley and others, 1998, p. 44). Mineral-production data are available from sources such as State geological and mining agencies, the USGS, and the Energy Information Administration. Few published water-use coefficients for mining are available and coefficients for many minerals must be determined from historical production and water-withdrawal data. Water withdrawals at mining operations can be highly variable and are dependent on several factors including the type of mineral produced or extracted, mining processes, water availability, and climate conditions.

Estimates of water withdrawals for various categories of use, including mining, are needed for water planning and management. Water-use data also are needed to evaluate the effects of human activity on the quantity and quality of the Nation's water resources over time. Use of consistent methods for estimating withdrawals for mining could help improve the accuracy and consistency of results and facilitate trend analysis.

\section{Purpose and Scope}

This report documents methods used to estimate withdrawals of fresh and saline 1 groundwater and surface water for mining during 2005 for each county and county equivalent in the United States, Puerto Rico, and the U.S. Virgin Islands. Withdrawals of water were estimated for nonfuels- and coalmining operations in all States and for oil and gas operations in six states. Nonfuels mining includes extraction of metallic and nonmetallic minerals. Metallic minerals include ores

\footnotetext{
${ }^{1}$ Saline water contains 1,000 milligrams per liter or more of dissolved solids.
}

of iron, copper, lead, zinc, gold, silver, ferroalloys, uranium, radium, vanadium, and others. Nonmetallic minerals include dimension and crushed stone, sand, gravel, various clays, chemical and fertilizer minerals, and various other nonmetallic, nonfuels minerals. Coal includes bituminous coal, lignite, and anthracite. Oil and gas includes crude petroleum, natural gas, and natural gas liquids (Office of Management and Budget, 1987, p. 39-47). All mining withdrawals are considered self-supplied. Use of the methods described in this report could result in more consistent water-withdrawal estimates for mining that can be used by water managers and planners to determine water needs and trends across the United States.

The results of this study were distributed to USGS National Water Use Information Program (NWUIP) personnel in each State during 2007. NWUIP personnel were required to submit estimated withdrawals for numerous categories of use in their State to a national compilation team for inclusion in a national report describing water use in the United States during 2005. NWUIP personnel had the option of submitting these estimates, a modified version of these estimates, or their own set of estimates or reported data. Estimated withdrawals resulting from the methods described in this report may not be included in the national report; therefore, the estimates are not presented herein in order to avoid potential inconsistencies with the national report. Water-use coefficients for specific minerals also are not presented in order to avoid potential disclosure of confidential production data provided by mining operations to the USGS.

\section{Acknowledgments}

The author gratefully acknowledges the assistance and cooperation of NWUIP personnel in each State who provided water-use coefficients for mining and other pertinent water-use data for their State. Thanks also to William Alley, Susan Hutson, Kristin Linsey, Joan Kenny, Molly Maupin, and Nancy Barber of the USGS for their guidance and input. Special thanks are given to Lucy McCartan, Robert Callaghan, and commodity specialists of the USGS Minerals Information Team for providing access to and assistance with mineralproduction data.

\section{Methods for Estimating Water Withdrawals for Mining}

Fresh and saline groundwater and surface-water withdrawals during 2005 for nonfuels- and coal-mining operations in each county or county equivalent in the United States, Puerto Rico, and the U.S. Virgin Islands were estimated by using the methods described herein. Fresh and saline groundwater withdrawals for oil and gas operations in counties in six states also were estimated. Total water withdrawals for mining in a county were estimated by summing estimated water withdrawals for nonfuels mining, coal mining, and oil 
and gas extraction in six states. Estimates are based on 2004 production data and water-use coefficients.

\section{Nonfuels and Coal Mining}

Water withdrawals for nonfuels and coal mining were estimated by using mine-production data and water-use coefficients. Production data for nonfuels mining during 2004 were obtained from the USGS Minerals Information Team (Robert M. Callaghan, U.S. Geological Survey, written commun., 2007). The data included the mine location and weight (in metric tons) of crude ore, rock, or mineral produced at each mine in the United States, Puerto Rico, and the U.S. Virgin Islands during 2004. Production data for coal mining during 2004 were from the Energy Information Administration's Annual Coal Report 2004 (Freme, 2005). The data included the weight (in metric tons) of coal produced in each county or county equivalent during 2004.

Water-use coefficients for mined commodities were compiled from various sources including published reports (U.S. Bureau of the Census, 1975, 1985; Mavis, 2002; Evans and others, 2003) and written communications from NWUIP personnel in several States. Additional water-use coefficients were derived by dividing reported or estimated water withdrawals for a mined commodity in selected States during 2000 by the reported weight of the mined commodity produced in those States during 2000. Reported or estimated water withdrawals for mines in selected States during 2000 were provided by NWUIP personnel in those States. Annual data for nonfuels mineral production during 2000 for the selected States were downloaded from the USGS Minerals Yearbook Web site accessed September 22, 2006, at URL http:// minerals.usgs.gov/minerals/pubs/state/index.html\#pubs. Coal production data from 2000 for the selected States were downloaded from the Energy Information Administration Web site accessed November 22, 2006, at URL http://www.eia.doe.gov/ cneaf/coal/cia/cia_html_tabs.html. For some commodities, coefficients varied greatly and median values were used. Coefficients for various minerals were grouped by 4-digit Standard Industrial Classification (SIC) (Office of Management and Budget, 1987). When no coefficient was available for a specific mineral, a coefficient for another mineral within the same 4-digit SIC group was used. Ranges of water-use coefficients used in this study for major (2-digit) SIC groups are presented in table 1.

The amount of water withdrawn and used for nonfuels mining and coal mining in each county or county equivalent during 2005 was estimated by using 2004 production data and water-use coefficients. For nonfuels mining, the amount of water (in gallons per year) used at each mine was determined by multiplying the weight (in metric tons) of crude ore, rock, or mineral produced at each mine by a water-withdrawal coefficient (in gallons per metric ton) for the type of ore, rock, or mineral produced. The results were then converted to million gallons per day and summed by county. For coal mining, the amount of water (in gallons per year) used in each
Table 1. Water-use coefficients for mining in the United States by major Standard Industrial Classification group (Office of Management and Budget, 1987).

[SIC, Standard Industrial Classification]

\begin{tabular}{clcc}
\hline $\begin{array}{c}\text { SIC } \\
\text { group } \\
\text { number }\end{array}$ & \multicolumn{1}{c}{$\begin{array}{c}\text { SIC group } \\
\text { description }\end{array}$} & \multicolumn{2}{c}{$\begin{array}{c}\text { Water-use coefficient } \\
\text { (gallons per short ton } \\
\text { of crude ore produced) }\end{array}$} \\
\cline { 2 - 4 } & Minimum & Maximum \\
\hline 10 & Metal mining & 140 & 1,567 \\
12 & Coal mining & 50 & 59 \\
14 & $\begin{array}{c}\text { Mining and quarrying of non- } \\
\text { metallic minerals, except fuels }\end{array}$ & 30 & 997 \\
\hline
\end{tabular}

county was determined by multiplying the weight (in metric tons) of coal produced in each county by a water-withdrawal coefficient (in gallons per metric ton) for coal. The results were then converted to million gallons per day. The estimated withdrawals for nonfuels mining and coal mining were summed by county.

Total water withdrawals for nonfuels and coal mining in each county or county equivalent were divided into withdrawals from groundwater, surface-water, freshwater, and salinewater sources based on the percentage of their respective withdrawals for mining in each county previously estimated by the USGS for (in order of preference) 2000, 1995, or 1990. Estimated groundwater, surface-water, freshwater, and saline-water withdrawals for mining in each county for 2000, 1995, and 1990 were downloaded on August 5, 2005, from the USGS Water-use Web site at URL http://water.usgs. gov/watuse/. The equations to divide total withdrawals into withdrawals from groundwater, surface-water, freshwater, and saline-water sources are as follows:

$$
\begin{aligned}
& W f w g w=W t *(W f w g w x / W t x) \\
& W s a g w=W t *(W s a g w x / W t x) \\
& W f w s w=W t *(W f w s w x / W t x) \\
& W s a s w=W t *(W \operatorname{sasw} x / W t x)
\end{aligned}
$$

where

$W f w g w=$ fresh groundwater withdrawals for nonfuels and coal mining in a county in 2005 , in million gallons per day;

$W t=$ total withdrawals for nonfuels and coal mining in the county in 2005, in million gallons per day;

$W f w g w x=$ fresh groundwater withdrawals for mining in the county in 2000, 1995, or 1990 (in order of preference);

$W t x=$ total withdrawals for mining in the county 2000, 1995, or 1990 (in order of preference); 


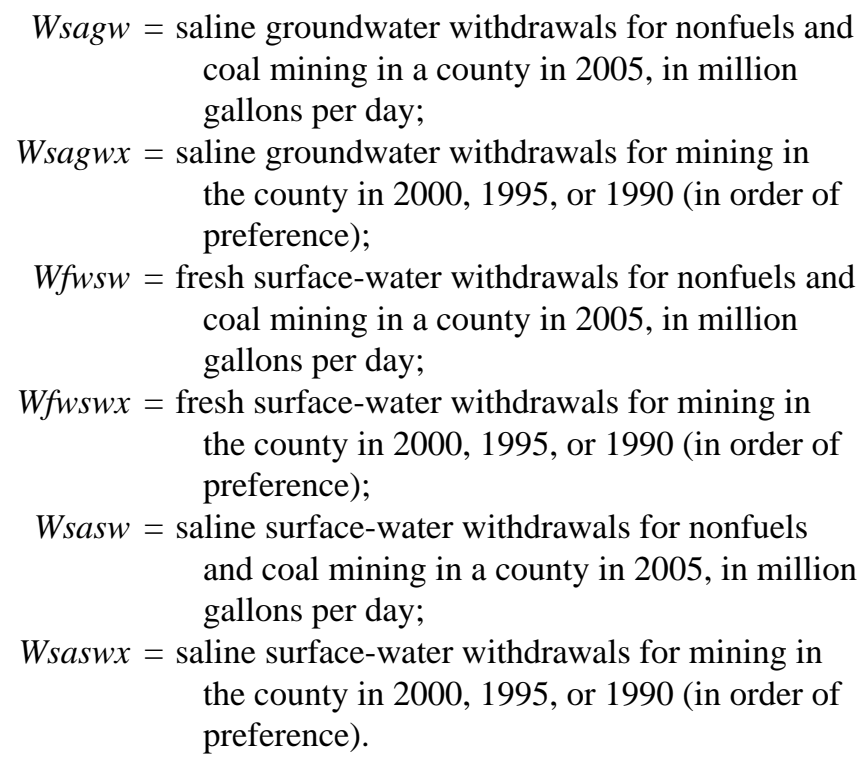

If there were estimated withdrawals for a county in 2005, but no withdrawals had been reported for the county since 1990, State average percentages of withdrawals by water source in 2005 were used. State average percentages of withdrawals by water source were calculated by summing estimated groundwater, surface-water, freshwater, and salinewater withdrawals for mining in all other counties in the State during 2005 and dividing these totals by the total withdrawals for mining in the counties.

\section{Oil and Gas Extraction}

Water withdrawals for oil and gas extraction were estimated for six states including California, Colorado, Louisiana, New Mexico, Texas, and Wyoming by using data from State agencies that regulate oil and gas extraction. These States, along with Alaska and Oklahoma, accounted for 85 percent or more of oil and gas produced in the United States during 2005 (Energy Information Administration, 2007). Water withdrawals for oil and gas extraction in other States were assumed to be minor, though they may be important at the county level. Water withdrawals for oil and gas extraction in Alaska and Oklahoma during 2005 were estimated by NWUIP personnel in those States, and discussions of those estimates are not included herein. Water, including water produced as a byproduct of oil and gas production, is used in association with many oil and gas activities; however, water injected for enhanced recovery comprises the bulk of the water used for oil and gas withdrawals (Railroad Commission of Texas, [no date]).

Records of water used at oil and gas fields generally are not available; however, volumes of water produced and/ or injected at oil and gas fields often are available from State agencies responsible for these activities and were used to estimate water withdrawals for oil and gas extraction in California, Colorado, Louisiana, New Mexico, Texas, and Wyoming. Sources of data and assumptions about the data used to estimate water withdrawals for oil and gas extraction are discussed by State below. Estimated water withdrawals for oil and gas extraction were summed by county, and the resulting totals were added to estimated withdrawals for nonfuels and coal mining in the six States.

\section{California}

Water withdrawn and used for oil and gas extraction in California was estimated based on records of water injected (henceforth called "injection water") at oil and gas fields in California during 2005, which were downloaded on June 26, 2007, from the California Department of Conservation-Division of Oil, Gas, and Geothermal Resources Web site at URL http://www.consrv.ca.gov/dog/prod_injection_db/index.htm. Data for each well included annual injection volume (in barrels); county; well type (cyclic steam, steamflood, waterflood, air injection, pressure maintenance, gas storage, liquefied petroleum gas injection, gas disposal, and water disposal); water source (produced from an oil or gas well, produced from a water well, obtained from a domestic supply, extracted from the ocean, waste from industrial facility, domestic waste disposal, or any other source or combination of sources); and kind of water (saline, fresh, water combined with chemicals, and other). Several assumptions were made, including:

1. Injection water for all well types other than "water disposal" was assumed to have been used beneficially.

2. Injection water that was produced from oil or gas wells, water-source wells, or any other source or combination of sources was considered a groundwater withdrawal. Injection water that was extracted from the ocean was considered a saline, surface-water withdrawal. Injection water from domestic water supplies, waste from industrial facilities, and domestic waste disposal were not considered self-supplied and were not included as withdrawals for oil and gas extraction.

3. Water combined with chemicals and any other kind of water other than fresh water was considered saline water.

\section{Colorado}

Water withdrawn and used for oil and gas extraction in Colorado was estimated based on records of water produced at oil and gas fields in Colorado during 2005, which were downloaded on June 29, 2007, from the Colorado Oil and Gas Conservation Commission Web site at URL http://oil-gas. state.co.us/library/statistics.html. Data for each well included county, volume of water produced, and water disposal codes ("undefined," "central disposal," "injection," "commercial disposal," "pit," and "surface discharge"). Several assumptions were made, including:

1. All produced water was assumed to be saline groundwater.

2. All produced water with the disposal code "injection" was assumed to be injected for secondary oil or gas recovery 
or some related beneficial use and was included as a withdrawal. Water with any other disposal code was assumed to be disposed of as waste, with no beneficial use, and was not included as a withdrawal.

\section{Louisiana}

Water withdrawn and used for oil and gas extraction in Louisiana was estimated based on records of saline water injected into the subsurface at oil and gas fields in Louisiana during 2005, which were obtained from the Louisiana Office of Conservation, Injection \& Mining Division (Joseph S. Ball, Jr., Louisiana Office of Conservation, written commun., 2007). Data for each well included parish and volumes of saline water that was injected. Water injected for beneficial use could not be separated from water injected for waste disposal; therefore, all water that was injected was assumed to be saline groundwater that was produced from oil or gas wells and was included as a withdrawal.

\section{New Mexico}

Water withdrawn and used for oil and gas extraction in New Mexico was estimated based on records of water injected at oil and gas fields in New Mexico during 2005, which were downloaded on June 29, 2007, from the Petroleum Recovery Research Center of New Mexico Web site at URL http:// octane.nmt.edu/gotech/Petroleum_Data/allwells.aspx. Data for each well included county, well type (gas, injection, oil, and saline water disposal), volume of water produced (in barrels), and volume of water injected (in barrels). Several assumptions were made, including:

1. Water injected in all well types other than saline water disposal was assumed to have been injected for secondary oil or gas recovery or some related beneficial use and was included as a withdrawal.

2. All water injected was assumed to be saline groundwater produced at the oil or gas field.

\section{Texas}

Water withdrawn and used for oil and gas extraction in Texas was estimated based on records of water injected at oil and gas fields in Texas during 2005, which were obtained from the Railroad Commission of Texas (Leslie Savage, Railroad Commission of Texas, written commun., 2007). The data included purpose of injection (disposal, secondary waterflood recovery, and miscellaneous) and volume of water injected (in barrels) in each county. Several assumptions were made, including:

1. Only water injected for secondary waterflood recovery was assumed to have been withdrawn for a beneficial use and was included as a withdrawal.
2. All of the injected water was assumed to be groundwater.

The water-withdrawal estimates were subdivided by fresh or saline water based on records of the number of wells permitted for injection of various fluid types in Texas during 2005, which also were obtained from the Railroad Commission of Texas (Fernando De Leon, written commun., 2007). The data included the number of wells injecting a specified type of water (fresh, brackish, saline, or a combination of water types) in each county. These data were used to determine the percentage of injected water that was fresh or saline. Several assumptions were made including:

1. All brackish water was assumed to be saline.

2. If a combination of water types was indicated, the contribution of each water type was assumed to be equal.

3. All wells were assumed to contribute equal volumes of water; the percentages were based on the number of wells injecting freshwater or saline water, rather than the volume injected of each water type, which was not provided.

\section{Wyoming}

Water withdrawn and used for oil and gas extraction in Wyoming was estimated based on records of water injected at oil and gas fields in Wyoming, which were obtained from the Wyoming Oil and Gas Conservation Commission (Robert Meyer, Wyoming Oil and Gas Conservation Commission, written commun., 2007). The data included the volume of water injected (in barrels) in each county. Water injected for beneficial use could not be separated from water injected for waste disposal. All water injected was assumed to be saline groundwater produced from oil or gas wells and was included as a withdrawal.

\section{Summary}

The mining water-use category includes groundwater and surface water that is withdrawn and used for nonfuels and fuels mining. Nonfuels mining includes the extraction of ores, stone, sand, and gravel. Fuels mining includes the extraction of coal, petroleum, and natural gas. Water is used for mineral extraction, quarrying, milling, and other activities directly associated with mining. For petroleum and natural gas extraction, water often is injected for secondary oil or gas recovery.

Estimates of water withdrawals for mining have been included in U.S. Geological Survey (USGS) reports describing water withdrawals for all categories of use in the United States since 1950 but were included in the self-supplied industrial use category from 1950 to 1980 . Mining withdrawals typically are less than one percent of total national water use and are relatively minor in most States when compared to withdrawals for other categories of use, such as public supply, irrigation, self-supplied industry, and thermoelectric power generation. 
Estimates of water withdrawals for various categories of use, including mining, are needed for water planning and management; however, records of water withdrawn and used at mining operations often are not available. Where water withdrawals for mining are unknown, they have often been estimated by using mineral-production data and water-use coefficients.

This report documents methods used to estimate withdrawals of fresh and saline groundwater and surface water for mining during 2005 for each county and county equivalent in the United States, Puerto Rico, and the U.S. Virgin Islands. Withdrawals of water were estimated for nonfuels and coal mining operations in all States and oil and gas operations in six States. Nonfuels mining includes extraction of metallic and nonmetallic minerals. Metallic minerals include ores of iron, copper, lead, zinc, gold, silver, ferroalloys, uranium, radium, vanadium, and others. Nonmetallic minerals include dimension and crushed stone, sand, gravel, various clays, chemical and fertilizer minerals, and various other nonmetallic, nonfuels minerals. Coal includes bituminous coal, lignite, and anthracite. Oil and gas includes crude petroleum, natural gas, and natural gas liquids. All mining withdrawals are considered self-supplied. Use of the methods described in this report could result in more consistent water-withdrawal estimates for mining that can be used by water managers and planners to determine water needs and trends across the United States.

The results of this study were distributed to NWUIP personnel in each State during 2007. NWUIP personnel were required to submit estimated withdrawals for numerous categories of use in their State to a national compilation team for inclusion in a national report describing water use in the United States during 2005. NWUIP personnel had the option of submitting these estimates, a modified version of these estimates, or their own set of estimates or reported data. Estimated withdrawals resulting from the methods described in this report may not be included in the national report; therefore, the estimates are not presented herein to avoid potential inconsistencies with the national report. Water-use coefficients for specific minerals also are not presented in order to avoid potential disclosure of confidential production data provided by mining operations to the USGS.

Fresh and saline groundwater and surface-water withdrawals during 2005 for nonfuels and coal mining operations in each county or county equivalent in the United States, Puerto Rico, and the U.S. Virgin Islands were estimated. Fresh and saline groundwater withdrawals for oil and gas operations in counties in six States also were estimated. Total water withdrawals for mining in a county were estimated by summing estimated water withdrawals for nonfuels mining, coal mining, and oil and gas extraction in six States.

Total water withdrawals for mining in a county were estimated by summing estimated water withdrawals for nonfuels mining, coal mining, and oil and gas extraction. Water withdrawals for nonfuels mining and coal mining were estimated using 2004 mine-production data and water-use coefficients. Production data for nonfuels mining included the mine location and weight (in metric tons) of crude ore, rock, or mineral produced at each mine in the United States, Puerto Rico, and the U.S. Virgin Islands during 2004. Production data for coal mining included the weight (in metric tons) of coal produced in each county or county equivalent during 2004. Water-use coefficients for mined commodities were compiled from various sources including published reports and written communications from NWUIP personnel in several States. Additional water-use coefficients were derived by dividing reported or estimated water withdrawals for a mined commodity in a State by the weight of the mineral produced in the State during 2000. Water withdrawals for oil and gas extraction were estimated for six States including California, Colorado, Louisiana, New Mexico, Texas, and Wyoming by using data from State agencies that regulate oil and gas extraction.

\section{Selected References}

Energy Information Administration, 2007, Petroleum supply annual 2006 - Volume 1: Washington, D.C., U.S. Department of Energy publication DOE/EIA-0340(06)/1, accessed November 22, 2006, at http://www.eia.doe.gov/oil_gas/petroleum/data_ publications/petroleum_supply_annual/psa_volume1/ psa_volume1.html

Evans, R., Roe, P., and Joy, J., 2003, Water use and sustainable development in coal mining - a case study from central Queensland: Brisbane, Australia, Minerals Council of Australia's Sustainable Development 03 Conference proceedings paper, 11 p., accessed December 8, 2006, at http://www.bowenbasin.cqu.edu.au/pdfs/waterusesota.pdf

Freme, Frederick, 2005, Annual Coal Report 2004: Washington , D.C., Energy Information Administration report DOE/ EIA-0584 (2004), 71 p., accessed November 22, 2006, at http://tonto.eia.doe.gov/FTPROOT/coal/05842004.pdf

Hutson, S.S., Barber, N.L., Kenny, J.F., Linsey, K.S., Lumia, D.S., and Maupin, M.A., 2004, Estimated use of water in the United States, 2000: U.S. Geological Survey Circular $1269,46 \mathrm{p}$.

MacKichan, K.A., and Kammerer, J.C., 1961, Estimated use of water in the United States, 1960: U.S. Geological Survey Circular 456, 26 p.

Mavis, J., 2002, Water use in industries of the future-mining industry, in Byers, W., Lindgren, G., Noling, C., and Peters, D., Industrial water management-a systems approach (2d ed.): New York, Center for Waster Reduction Technologies, American Institute of Chemical Engineers, 295 p., accessed December 8, 2006, at http://wwwl.eere.energy.gov/industry/mining/pdfs/ water_use_mining.pdf

Murray, C.R., 1968, Estimated use of water in the United States, 1965: U.S. Geological Survey Circular 556, 53 p. 
Murray, C.R., and Reeves, E.B., 1972, Estimated use of water in the United States, 1970: U.S. Geological Survey Circular 676, $37 \mathrm{p}$.

Murray, C.R., and Reeves, E.B., 1977, Estimated use of water in the United States, 1975: U.S. Geological Survey Circular $765,37 \mathrm{p}$.

Office of Management and Budget, 1987, Standard industrial classification manual: Washington, D.C., Executive Office of the President, U.S. Government Printing Office, 705 p.

Quan, Choon K., 1988, Water use in the domestic nonfuel minerals industry: Bureau of Mines Information Circular 9196, 67 p.

Railroad Commission of Texas, [no date], Water use in association with oil and gas activities regulated by the Railroad Commission of Texas: Crude Oil and Natural Gas, General Information, 6 p., accessed December 8, 2006, at http://www.rrc.state.tx.us/divisions/og/wateruse.html

Solley, W.B., Chase, E.B., and Mann, W.B., IV, 1983, Estimated use of water in the United States, 1980: U.S. Geological Survey Circular 1001, 56 p.
Solley, W.B., Merk, C.F., and Pierce, R.R., 1988, Estimated use of water in the United States, 1985: U.S. Geological Survey Circular 1004, 82 p.

Solley, W.B., Pierce, R.R., and Perlman, H.A., 1993, Estimated use of water in the United States, 1990: U.S. Geological Survey Circular 1081, 76 p.

Solley, W.B., Pierce, R.R., and Perlman, H.A., 1998, Estimated use of water in the United States, 1995: U.S. Geological Survey Circular 1200, 71 p.

U.S. Bureau of the Census, 1975, 1972 Census of mineral industries-Subject series-Water use in mineral industries: U.S. Department of Commerce publication MIC72(1)-2, $65 \mathrm{p}$.

U.S. Bureau of the Census, 1985, 1982 Census of mineral industries-Subject series-Water use in mineral industries: U.S. Department of Commerce publication MIC82-S-4, $52 \mathrm{p}$. 
